\title{
Using Peer Tutoring to Improve Students' Academic Achievement in Financial Accounting Concepts
}

\author{
Taiwo Grace Olulowo, ${ }^{1}$ Olugbenga A. Ige $\mathbb{C}^{2},{ }^{2}$ and Ernest O. Ugwoke $\mathbb{D}^{3}$ \\ ${ }^{1}$ Department of Social Science Education, Faculty of Education, Adekunle Ajasin University, Akungba Akoko, Nigeria \\ ${ }^{2}$ School of Social Sciences and Language Education, University of the Free State, Bloemfontein, South Africa \\ ${ }^{3}$ Department of Business Education, University of Nigeria, Nsukka, Nigeria
}

Correspondence should be addressed to Olugbenga A. Ige; olugbengaige@gmail.com and Ernest O. Ugwoke; ernest.ugwoke@unn.edu.ng

Received 12 June 2020; Accepted 28 August 2020; Published 22 September 2020

Academic Editor: Gérard Lassibille

Copyright ( 2020 Taiwo Grace Olulowo et al. This is an open access article distributed under the Creative Commons Attribution License, which permits unrestricted use, distribution, and reproduction in any medium, provided the original work is properly cited.

\begin{abstract}
This study investigated the effectiveness of the peer tutoring instructional strategy in improving students' academic achievement in financial accounting concepts. A nonrandomized pretest-posttest control group quasi-experimental design with a $2 \times 2 \times 3$ factorial matrix was adopted. The research sample comprised 137 purposively selected students from eight intact classes in secondary schools in Southern Nigeria. The experimental group adopted a peer tutoring instructional strategy, while the control group was exposed to the conventional lecture method. Teachers' Instructional Guides on peer tutoring and conventional method and Financial Accounting Achievement Test were used to collect data for this study. Results affirmed that the peer tutoring instructional strategy is more effective in improving students' academic achievement in financial accounting concepts than the conventional lecture method. The outcome of this study also shows that the experimental strategy was not sensitive to gender but sensitive to socioeconomic status. Sequel to this finding, the study recommends that post-basic school teachers should make use of the peer tutoring instructional strategy to present financial accounting lessons in secondary schools to advance students' attainment in the subject.
\end{abstract}

\section{Introduction}

Education is a vital tool used by every society to transform her citizens to become more useful, competent, and selfreliant and to inculcate into them required skills, competencies, and abilities needed to become functional in the society. The major goals of education at all echelons in Nigeria are the acquisition of appropriate skills, competencies, and abilities mentally and physically as an instrument for an individual to be highly productive and contribute their quota to the advancement of the society [1]. These objectives of education are taught at the primary, secondary, and tertiary educational levels in Nigeria.

At the secondary school echelon, the worth of teaching and learning should be practical-oriented for effectual indoctrination of principles, basic concepts, skills, and competencies needed for useful living and self-reliance to those whose education is terminated at the secondary school level and preparing those who want to further to the tertiary level [2]. Consequent upon the magnitude of education to the development of Nigeria in all spheres, the Federal Republic of Nigeria authorized the introduction of vocational subjects in all secondary schools [3]. It is in the light of this that financial accounting was introduced as one of the vocational subjects in senior secondary schools. This action geared towards furnishing students with pertinent skills, knowledge, and competence required for self-reliance, profitable employment, national growth, and development [3].

Asaolu [4] defined financial accounting as the process of recording, classifying, selecting, measuring, interpreting, summarizing, and reporting financial information of an organization to internal and external users for decisionmaking and proper appraisal. It is also the process of collecting, recording, summarizing, analyzing, and reporting 
the worth of a business organization in monetary terms and providing financial information for users for future investment. Abbey and Okorogba [5] defined financial accounting as essentially a course that involves the acquisition, management, and keeping of business transaction records. Inuwa et al. [6] stated that the goals of inclusion of financial accounting as a subject in Nigerian secondary schools are to enable learners to value fundamental practices of accounting, principles, and applications to newfangled business activities that prepare them for future engagements in the field of accounting (see [7]). Other scholars affirmed that accounting is very crucial to the nation's economy based on its ability to provide the basis for skilled workforce needed for accounting and related professions $[8,9]$.

In spite of the laudable and lofty objectives of financial accounting and its colossal significance to the individual and national development, secondary school students' learning outcomes in accounting concepts over the years need improvement, particularly in national examinations [6, 9-14]. In a similar vein, Obidile et al. [15] opined that students' academic achievement in the subject has not been encouraging especially at the secondary level of education. Furthermore, Onyali et al. [16] averred that the incidences of students' poor academic achievement in mathematical subjects such as financial accounting remain unabated despite the unrelenting efforts of the government to foster the achievement of learners; hence, it becomes expedient to find philosophical ways of improving students' learning outcomes in financial accounting.

Nwaukwa and Okolocha [17] asserted that financial accounting is a subject that cannot be mastered by rote learning and memorization of basic concepts and principles but has a need of sound theoretical knowledge and intensive practice in its application due to its procedural and organized nature. Umar and Abdulmutallib [18] opined that conventional method (lecture) of teaching has continued to dominate Nigerian classroom teaching. Conventional (lecture) method of teaching has its own usefulness but may not be an effective instructional method for improving students' achievement in skill-based subjects because students' involvement in teaching and learning process is low, and this makes students rely on their teachers for their learning needs $[11,13,17,19,20]$. In the light of these developments, it becomes expedient to research on suitable instructional strategies to foster students' achievement in accounting concepts in secondary schools to adequately prepare them for both internal and external examinations.

Melero and Fernandez [21], Rudland and Rennie [22], and Flores et al. [23] stated that the importance of the peer tutoring instructional strategy includes improving students' academic performance, communication skill, and enthusiasm to learn. It also instills sense of responsibility and builds self-confidence. Students are more involved in learning when they work with other peers $[24,25]$ because they feel more connected with their peers when learning [26, 27]. In addition, it enables them to work as a team, provide, and accept response and appraise their learning activities [27].

Fundamentally, peer tutoring refers to learning environment where students learn together and from each other as equal learners without exerting authority to any learner based on the ideology that "students learn a great deal by explaining their ideas to others and by participating in activities in which they can learn from their peers." [28] Consequently, peer tutoring upholds intellectual development and improves academic and social skills for both tutor and tutee [29, 30]. Inuwa et al. [9] asserted that peer tutoring is one of the learner-centered strategies which is an effective strategy to improve students' academic achievement and other related learning outcomes. In a study conducted by Azubuike [31], slow learners who were taught biology concepts using the peer tutoring instructional strategy performed higher than learners who were taught biology using the expository method.

Several studies affirmed that gender is connected to the learning outcomes of students in secondary schools, most especially academic achievement [32-35]. In the same vein, Kyei and Apam [36] found that male students were performing better than the female students in senior high school mathematics examination in the Upper East Region of Ghana. In the light of the foregoing, it, therefore, becomes expedient to ascertain the connection of gender to students' achievement in financial accounting.

Apart from gender, socioeconomic status is a variable that could affect students' learning outcomes in accounting teaching and learning. According to Guo and Harris [37] in [38], socioeconomic background is the relative standing of a family in a society based on its income, power, background, and prestige. Rathe and Sharma [39] also indicated that the academic skill development of children from low social economic status (SES) households and communities was not comparable to children from the higher socioeconomic status group. It is expected that findings of this discourse would unveil the adequacy of peer tutoring to students offering financial accounting in the selected secondary schools.

The paucity of research on the effectiveness of peer tutoring in accounting-related fields made it imperative to scrutinize the efficacy of the peer tutoring instructional strategy on the academic achievement of students in financial accounting concepts with consideration of gender and socioeconomic status as the confounding variables. However, studies by Moliner and Alegre [40] on the effectiveness of peer tutoring on students' mathematics selfconcepts in middle schools suggested that prospective study should tackle the efficiency of this teaching method across different countries and within different instructive settings; hence, this study scrutinizes the effectiveness of peer tutoring in improving the academic achievement of students in financial accounting concepts in Ondo State, Nigeria, following the suggestions of Moliner and Alegre [40].

\section{Literature Review}

The goal of applying modern strategies to delivery of financial accounting instruction is to improve quality of education, students' level of confidence, independence, and influence over financial accounting concepts [41] in [42]. Peer tutoring is an effective instructional strategy that enhances students' enclosure while facilitating students to 
learn from one another [43]. Peer tutoring is an approach which helps to improve both academic skills and social behavior. It is described as an instructional strategy that makes use of peers to provide one-on-one instruction and give detailed explanation of concepts [44] in [45]. Peer tutoring is a valuable instructional strategy that makes peers mutually dependent and gives task to both tutor and tutee. It helps to improve students' social skills and provides emotional support [46-54]. The importance of the peer tutoring instructional strategy includes improving students' academic performance, communication skills, and enthusiasm to learn [21-23]. It also instills sense of responsibility and builds self-confidence.

Scholars defined peer tutoring as a collaborative strategy that pairs learners who share common educational outcomes $[40,55]$. Moliner and Alegre [40] stated that these goals are achieved in a structure in which learners have no mutual relationship related to their personal academic proficiency. One of the students in each pair acts as a tutor while another plays tutee [40]. Tutees ask tutors academic questions to acquire knowledge (see [56]). The major position of the academic tutors is to be of assistance to the tutees and react to their response during the course of learning as tutors are higher academic achievers than the tutees [57]. Both tutors and tutees stand to gain from this instructional strategy. Tutees are at an advantage as they receive direct teaching from a peer. Tutees usually feel more relaxed to ask questions from the tutors since they share a similar exposition and better understand the learning content [58]. Tutors are also at an advantage as their knowledge is strengthened as they provide answers to the tutees' questions. The connections between tutees and tutors uphold participatory learning and promote learner's involvement in learning as the entire learners take part in the learning process $[59,60]$.

The effectiveness of the peer tutoring instructional strategy on students' learning outcomes in related disciplines is well documented in the current literature (see [61]). An important study, AbdulRaheem et al. [62], investigated the influence of peer tutoring and gender on students' academic performance in economics. AbdulRaheem et al. [62] reported that peer tutoring was effective in promoting students' achievement in secondary school economics. In a related study, Ogundola [61] examined the influence of peer tutoring on students' achievement in technical drawing using an experimental study of a quasi-type. Ogundola [61] observed that the peer tutoring instructional strategy was more effective in improving students' academic achievement than the conventional teaching method. Moliner and Alegre [40], in the context of Spain, examined the effectiveness of peer tutoring on students' mathematics self-concepts in a middle school and reported arithmetically noteworthy developments for the grades exposed to peer tutoring. It is considering this background that the following hypotheses are, therefore, tested in this study:

$\mathrm{H}_{01}$ : there is no significant main effect of treatment on students' achievement in financial accounting concepts

$\mathrm{H}_{02}$ : there is no significant main effect of gender on students' achievement in financial accounting concepts
$\mathrm{H}_{03}$ : there is no significant main effect of socioeconomic status on students' achievement in financial accounting concepts

$\mathrm{H}_{04}$ : there is no significant interaction effect of treatment and gender on students' achievement in financial accounting concepts

$\mathrm{H}_{05}$ : there is no significant interaction effect of treatment and socioeconomic status on students' achievement in financial accounting concepts

\section{Method}

3.1. Research Design. The study adopted nonrandomized pretest-posttest control group quasi-experimental design (see $[32,33,63,64])$. Specifically, this study adopted the quasi-experimental design because it allowed the researchers to manipulate the variables of interest in this study. The design is represented schematically in the following:

$$
\begin{array}{ll}
\mathrm{O}_{1} X_{1} \mathrm{O}_{3} & \text { experimental group. } \\
\mathrm{O}_{2} X_{2} \mathrm{O}_{4} & \text { control group. }
\end{array}
$$

$\mathrm{O}_{1}$ and $\mathrm{O}_{2}$ are the pretest of experimental and control groups, respectively. $\mathrm{O}_{3}$ and $\mathrm{O}_{4}$ represent the posttest of experimental and control groups, respectively.

$X_{1}$-peer tutoring instructional strategy.

$X_{2}$-conventional lecture method (Table 1).

The study, therefore, adopted a $2 \times 2 \times 3$ factorial matrix which consisted of instructional strategy at two levels of treatment (peer tutoring instructional strategy and conventional lecture method), intervening variables of gender at two levels (male and female), and socioeconomic status at three levels (low, middle, and high) (see [34]). Ige [65] affirmed that the use of factorial matrix in an experimental study provides data discipline.

3.2. Participants. The population of this study consisted of all the senior school two students offering financial accounting in Ondo North Senatorial District of Ondo State, Nigeria, from which one hundred and thirty-seven students were purposefully selected to participate in the experimental and control group activities. The participants were selected for the experimental and control group activities because financial accounting is taught in senior secondary schools in Nigeria. Also, the students were selected for the study because they were not preparing for the external examinations. Consequent on this, the students were readily available to participate in the study. Eight senior secondary school II classes were selected in each of the eight secondary schools. Four schools were assigned to the peer tutoring instructional strategy (53 students) and the other four schools to the conventional strategy (84 students). The schools were selected based on the following criteria:

(i) The school should be a coeducational governmentowned school

(ii) The school must be offering financial accounting as one of the business subjects and also be registered by 
TABLE 1: $2 \times 2 \times 3$ factorial matrix.

\begin{tabular}{lccc}
\hline \multirow{2}{*}{ Treatment } & \multirow{2}{*}{ Gender } & Socioeconomic status \\
& & Middle & High \\
\hline Peer tutoring instructional & Male & & \\
strategy E1 & Female & & \\
Conventional lecture & Male & & \\
method E2 & Female & \\
\hline
\end{tabular}

the West African Examinations Council (WAEC) and National Examination Council (NECO) as a centre for conducting Senior Secondary Certificate in Education (SSCE) examination in the subject

(iii) Accessibility of the school

3.3. Research Instruments. In this study, three instruments were utilized: Financial Accounting Achievement Test (FAAT), Teachers' Instructional Guide for Peer Tutoring Instructional Strategy (TIGPTIS), and Teachers' Instructional Guide for Conventional Lecture Method (TIGCLM). The TIGPTIS and TIGCLM were designed by the researcher to guide teachers in experimental and control groups, respectively. This was done to ensure conformity to the research method. The instructional guide was validated by experts from the Department of Business Education (accounting option), University of Nigeria, Nsukka. The experts' reviews and comments were used to improve the instruments. The FAAT consists of sections $\mathrm{A}$ and B. Section A sought for personal data of the respondent such as gender, class, name of school, parents' educational qualification, parents' occupation, and parents' income per month, while section B contained 30 adapted multiple choice questions from the WASSCE past questions. Depreciation of fixed asset, manufacturing accounts, and accounts for nonprofit-making organizations were the content area of the FAAT. FAAT reliability yielded 0.83 using Kuder-Richardson Formula 21.

3.4. Experimental Procedure. The treatment and data collection procedure was in four main phases and lasted for eight weeks $\left(1^{\text {st }}\right.$ week for training of the research assistant, $2^{\text {nd }}$ week for the administration of the pretest, $3^{\text {rd }}-7^{\text {th }}$ weeks for the application of treatment on experimental and control groups, and $8^{\text {th }}$ week for the administration of the posttest). In the first week, the researcher followed the experimental procedure outlined by Eze et al. [20], which included briefing the teachers that acted as research assistants on the fundamental course of actions before the commencement of the experimental activities. In the second week, the pretest was administered on the participants in the experimental and control groups by the research assistants to determine the students' abilities before the experimental activities were started. The treatment lasted for seven weeks. Teaching was conducted during the normal school period using the school timetable. The students were taught once a week for five weeks using 80 minutes per week. In the eighth week, posttest was administered to the subjects in the two groups by the class teachers to reduce the Hawthorne effect which would be introduced if the researcher administers the test. Data collected during the experimental and control activities were used to test the hypotheses raised for this study.

3.4.1. Peer Tutoring Instructional Strategy (Experimental Group). Treatment in this group involved the following steps:

Step 1: teacher presented the topic to be taught to the students

Step 2: teacher paired the students into groups (tutee) and a peer among the student which served as the tutor in the group

Step 3: the tutor in each group taught and explained the topic to other members which are the tutees under the supervision of the teacher

Step 4: teacher gave questions on the topic to the students in order to know to which extent they have learnt from the tutor

Step 5: students answered the questions individually without the assistance from the tutor

Step 6: teacher summarized the lesson

Step 7: teacher evaluated the students

Step 8: students were given a take-home assignment

3.4.2. Conventional Instructional Strategy (Control Group). Control group was taught using the following steps:

Step 1: teacher presented the lesson in the form of a lecture

Step 2: students listened to the teacher's explanation on the topic

Step 3: students wrote down summaries in the form of note from the chalkboard

Step 4: students asked the teacher questions on areas of the topic that are not clear to them

Step 5: teacher summarized the lesson

Step 6: teacher evaluated the students

Step 7: students were given a take-home assignment

3.5. Ethical Issues. The Departmental Research Board in Business Education at the Faculty of Vocational and Technical Education in University of Nigeria, Nsukka, authorized this research. Despite the approval by this research board, permissions and informed consent were obtained from the School Management Teams of the eight schools selected for this study.

3.6. Data Analysis. Descriptive statistics such as mean and standard deviation were utilized to show the performance in the experimental groups across gender and socioeconomic status (see [32]). The hypotheses were tested at the 0.05 level of significance using analysis of covariance (ANCOVA). 
Therefore, the null hypothesis of no significant effect was upheld when the $p$ value reached a level of significance that is greater than 0.05 . On the contrary, the null hypothesis of no significant effect was not upheld when the $p$ value reached a level of significance that is less than 0.05. Ige and Hlalele [34] posited that ANCOVA is a valuable statistical tool to analyse the data collected in an experimental study because it would enable the researcher to explore the effect of the independent and confounding variables on the dependent variable. The use of ANCOVA in this study is also justified by the confirmations of Ting [66] that it has a stratification factor and Ige [33] that ANCOVA partial out the initial incongruities in the pretest scores. Additionally, the estimated marginal means (EMM) was used to determine the magnitude and direction of the differences among the groups with significant effect. Bonferroni post hoc analysis was further used to identify the sources of significant differences where they existed. The coded data analysis was analysed with Statistical Package for Social Sciences (SPSS) 25.0.

\section{Findings}

The data analysed were presented to test the hypotheses that guided this study:

$\mathrm{H}_{01}$ : there is no significant main effect of treatment on students' achievement in financial accounting concepts

Table 2 shows that there is a significant main effect of the treatment on students' achievement in financial accounting concepts $\left(F_{(1,124)}=196.451 ; p<0.05\right.$; $\left.\eta^{2}=.613\right)$. The effect size is $61 \%$ which implies that $61 \%$ of the variance in the dependent variable is attributed to the independent variable. The ANCOVA output shows there is a significant difference in the achievement of students who were taught using the peer tutoring instructional strategy and conventional lecture method. The first hypothesis is therefore rejected. To enable the researchers determine the magnitude of the significant main effect in the treatment groups, the estimated marginal means is presented in Table 3.

Table 3 reveals that students exposed to the peer tutoring instructional strategy performed better $(\bar{x}=23.30)$ than those in the control group $(\bar{x}=15.65)$. This order is represented as PTIS > CLM. Furthermore, the source of the significant difference obtained in Table 4 was traced using Bonferroni post hoc test.

From Table 4, the Bonferroni post hoc analysis shows that there was a significant difference between PTIS and CLM. This, therefore, means that PTIS was significantly more effective than CLM.

$\mathrm{H}_{02}$ : there is no significant main effect of gender on students' achievement in financial accounting concepts

Table 2 shows that there is no significant main effect of gender on students' achievement in financial accounting concepts $\left(F_{(1,124)}=3.094, p>0.05 ; \eta^{2}=.024\right)$. Therefore, the null hypothesis is not rejected. This implies that there was no significant difference in the postachievement test scores of the male and female students. This means that the efficacies of the instructional strategies were not influenced by the students' gender.

$\mathrm{H}_{03}$ : there is no statistically significant effect of socioeconomic status on academic achievement of students in financial accounting concepts

Table 2 also shows that there exists statistically significant effect of SES on academic achievement of students in financial accounting concepts $\left(F_{(2,124)}=3.589, p<0.05 ; \eta^{2}=.055\right)$. Therefore, the null hypothesis is rejected. This implies that there was a significant difference in the postachievement test scores of the students based on their SES. This means that the efficacies of the instructional strategies were influenced by the students' gender. The estimated marginal means of the groups is presented to determine the magnitude of the significant main effect across SES in Table 5.

Table 5 reveals that high SES financial accounting students had the higher achievement mean score $(\bar{x}=19.88)$ followed by the middle SES financial accounting students with the achievement mean score of $\bar{x}=19.44$, while low SES financial accounting students had lower achievement mean score $(\bar{x}=19.11)$. This implies that high SES students achieve more than the middle and low SES students.

$\mathrm{H}_{04}$ : there is no significant interaction effect of treatment and gender on students' achievement in financial accounting concepts

Table 2 shows that there was no significant two-way interaction effect of treatment and gender on students' achievement in financial accounting concepts $\left(F_{(1,124)}=2.502, p>0.05 \eta^{2}=0.20\right)$. This implies that treatment and gender had no significant interaction effect on students' achievement in financial accounting concepts. Consequent on this result, the null hypothesis was, therefore, not rejected.

$\mathrm{H}_{05}$ : there is no significant interaction effect of treatment and socioeconomic status on students' achievement in financial accounting concepts

Table 2 shows that there was a significant two-way interaction effect of treatment and socioeconomic status on students' achievement in financial accounting concepts $\left(F_{(2,124)}=6.840, p<0.05 \eta^{2}=0.99\right)$. This implies that treatment and socioeconomic status had significant interaction effect on students' achievement in financial accounting concepts. The null hypothesis was, therefore, rejected in the light of this result. The results presented in Table 2 imply that the interplay of treatment students was exposed and their parents' SES had an effect on students' achievement in financial accounting. The estimated marginal means of the groups that determined the magnitude of the significant interaction effect of treatment and SES is presented in Table 6. 
TABLE 2: Summary of analysis of covariance (ANCOVA) of postachievement test of students by treatments, gender, and SES. Dependent variable: postachievement test.

\begin{tabular}{|c|c|c|c|c|c|c|}
\hline Source & Type III sum of squares & Df & Mean square & $F$ & Sig. & Partial eta-squared \\
\hline Corrected model & $3712.755^{\mathrm{a}}$ & 12 & 309.396 & 180.665 & 0.000 & 0.946 \\
\hline Intercept & 265.135 & 1 & 265.135 & 154.820 & 0.000 & 0.555 \\
\hline Pretest & 56.234 & 1 & 56.234 & 32.837 & 0.000 & 0.209 \\
\hline Treatment & 336.429 & 1 & 336.429 & 196.451 & 0.000 & 0.613 \\
\hline Gender & 5.299 & 1 & 5.299 & 3.094 & 0.081 & 0.024 \\
\hline SES & 12.292 & 2 & 6.146 & 3.589 & 0.031 & 0.055 \\
\hline Treatment $*$ gender & 4.284 & 1 & 4.284 & 2.502 & 0.116 & 0.020 \\
\hline Treatment $*$ SES & 23.427 & 2 & 11.713 & 6.840 & 0.002 & 0.099 \\
\hline Gender $*$ SES & 0.730 & 2 & .365 & 0.213 & 0.808 & 0.003 \\
\hline Treatment $*$ gender $*$ SES & 4.345 & 2 & 2.173 & 1.269 & 0.285 & 0.020 \\
\hline Error & 212.355 & 124 & 1.713 & & & \\
\hline Total & 51277.000 & 137 & & & & \\
\hline Corrected total & 3925.109 & 136 & & & & \\
\hline
\end{tabular}

$R^{2}=.946$ (adjusted $R^{2}=.941$ ), computed using alpha $=.05$.

TABLE 3: Estimated marginal means for the postachievement test.

\begin{tabular}{lcccc}
\hline Treatment & Mean & Std. error & \multicolumn{2}{c}{$95 \%$ confidence interval } \\
& & & Lower bound & Upper bound \\
\hline Peer tutoring (PT) & $23.302^{\mathrm{a}}$ & 0.350 & 22.609 & 23.996 \\
Conventional & $15.648^{\mathrm{a}}$ & 0.243 & 15.167 & 16.129 \\
\hline
\end{tabular}

${ }^{\mathrm{a}}$ Covariates appearing in the model are evaluated at the following values: pretest $=11.4307$.

TABLE 4: Bonferroni post hoc analysis of the postachievement test.

\begin{tabular}{|c|c|c|c|c|c|c|}
\hline \multirow[t]{2}{*}{ (I) treatment } & \multirow[t]{2}{*}{ (J) treatment } & \multirow[t]{2}{*}{ Mean difference (I-J) } & \multirow[t]{2}{*}{ Std. error } & \multirow[t]{2}{*}{ Sig. ${ }^{b}$} & \multicolumn{2}{|c|}{$\begin{array}{l}\text { 95\% confidence interval for } \\
\text { difference }\end{array}$} \\
\hline & & & & & Lower bound & Upper bound \\
\hline Peer tutoring & Conventional & $7.654^{*}$ & 0.546 & 0.000 & 6.573 & 8.735 \\
\hline Conventional & Peer tutoring & $-7.654^{*}$ & 0.546 & 0.000 & -8.735 & -6.573 \\
\hline
\end{tabular}

Based on estimated marginal means, ${ }^{*}$ indicates the mean difference is significant at the 0.05 level. ${ }^{b}$ Multiple comparisons' adjustment: Bonferroni.

TABLE 5: Estimated marginal means for the achievement test by SES.

\begin{tabular}{lcccc}
\hline \multirow{2}{*}{ SES } & \multirow{2}{*}{ Mean } & Std. error & \multicolumn{2}{c}{$95 \%$ confidence interval } \\
& & & Lower bound & Upper bound \\
\hline High & $19.877^{\mathrm{a}}$ & 0.201 & 19.478 & 20.275 \\
Middle & $19.435^{\mathrm{a}}$ & 0.207 & 19.024 & 19.845 \\
Low & $19.114^{\mathrm{a}}$ & 0.221 & 18.677 & 19.552 \\
\hline
\end{tabular}

${ }^{\mathrm{a}}$ Covariates appearing in the model are evaluated at the following values: pretest $=11.4307$

Table 6 shows the output of the estimated marginal means of students' achievement in financial accounting by treatment and SES, with high socioeconomic status (24.22) benefitted most from the treatment followed by middle socioeconomic status (23.29) and students with low-middle socioeconomic status (22.40).

\section{Discussion}

This study experimented if peer tutoring instructional strategies would improve students' achievement in financial accounting concepts compared to the conventional lecture method. The first strand of analysis was the main effect of treatment on participants' achievement in the financial accounting concepts selected from the financial accounting syllabus which is hypothesis one. The achievement of the participants in financial accounting concepts improved after receiving the treatments given to the experimental group. The participants exposed to peer tutoring had greater improvement in their attainment of financial accounting concepts. This result shows the effectiveness of peer tutoring on participants' academic achievement in financial accounting.

Okoye [67] affirmed that the efficacy of the peer tutoring instructional strategy could be connected to students' active involvement in the learning process. Peer tutoring allows the transfer of control to the students in the classroom under the supervision of the teacher; it gives students the opportunity to explain their thought process in such a way that the other students will easily comprehend. The participants expressed their opinions freely and asked questions from the teachers that participated in the experimental activities. In a similar vein, Melero and Fernandez [21], Rudland and Rennie [22], and Flores et al. [23] stated that the importance of the peer tutoring instructional strategy includes improving students' 
TABLE 6: Treatment and SES estimated marginal means for the achievement test.

\begin{tabular}{|c|c|c|c|c|c|}
\hline \multirow{2}{*}{ Treatment } & \multirow{2}{*}{ SES } & \multirow{2}{*}{ Mean } & \multirow{2}{*}{ Std. error } & \multicolumn{2}{|c|}{ 95\% confidence interval } \\
\hline & & & & Lower bound & Upper bound \\
\hline \multirow{3}{*}{ Peer tutoring } & High & $24.216^{\mathrm{a}}$ & 0.425 & 23.375 & 25.056 \\
\hline & Middle & $23.289^{\mathrm{a}}$ & 0.432 & 22.434 & 24.145 \\
\hline & Low & $22.402^{\mathrm{a}}$ & 0.451 & 21.509 & 23.294 \\
\hline \multirow{3}{*}{ Conventional } & High & $15.538^{\mathrm{a}}$ & 0.320 & 14.906 & 16.170 \\
\hline & Middle & $15.827^{\mathrm{a}}$ & 0.328 & 15.178 & 16.476 \\
\hline & Low & $15.580^{\mathrm{a}}$ & 0.310 & 14.966 & 16.193 \\
\hline
\end{tabular}

${ }^{a}$ Covariates appearing in the model are evaluated at the following values: pretest $=11.4307$.

academic performance, communication skills, and enthusiasm to learn. It also instills sense of responsibility and builds self-confidence. This finding is in tandem with the discovery of AbdulRaheem et al. [62], Ogundola [61], Abdullahi [68], Udo [69], Tella [70], and Okoye [67] who, in their separate studies, reported that students exposed to the peer tutoring instructional strategy were superior to others who were taught with the conventional lecture method in economics, technical drawing, mathematics, basic science, and home economics. This finding is also in harmony with the result of Moliner and Alegre [40], in the context of Spain, who investigated the effectiveness of peer tutoring on students' mathematics self-concepts in middle schools and reported arithmetically noteworthy outcomes for the experimental groups exposed to peer tutoring (see [71-73]).

The second hypothesis hypothesized that gender would not significantly affect the achievement of the participants in financial accounting concepts. The outcomes of the data analysed in this study showed that there was no significant difference in the postattainment scores of male and female participants in financial accounting concepts. This finding is in harmony with the outcome of a research conducted by Ige and Hlalele [34] that affirmed gender had no influence on students' academic attainment in civic education concepts. Similarly, this finding also conforms with the findings of Chinwuba and Osamuyimen [74], Ezenwosu and Nworgu [75], Dania [76], Abdullahi [68], AbdulRaheem et al. [62], and Adewale and Effiong [77] who found in their separate research that gender did not have a significant main effect on students' achievement in accounting, biology, social studies, mathematics, and economics, respectively. The influence of gender on the academic achievement of students in financial accounting concepts observed in this study implies that the peer tutoring instructional strategy is advantageous for teaching both male and female students, that is, it is not gender-biased. This finding contradicted Ige's finding [33] that affirmed that gender had influence on learners' academic attainment in ICT concepts in social studies.

The effect of socioeconomic status was significant on the achievement of the participants in financial accounting concepts. Findings reveal that high SES financial accounting students had the highest achievement mean score $(\bar{x}=19.88)$ followed by the middle SES financial accounting students with the achievement mean score of $\bar{x}=19.44$, while low SES financial accounting students had lower achievement mean score $(\bar{x}=19.11)$. This implies that high SES students achieve more than the middle and low SES students. This finding agrees with the findings of Ebong [78], Mgbado [79], and Tina [80] who reported in their separate studies that students from the high socioeconomic status are found to perform higher than the students from the middle and low socioeconomic status because family standard is one of the predictors of the child's future achievement.

Students' gender and treatment do not significantly interact to influence students' achievement in financial accounting concepts. This means that the peer tutoring instructional strategy is not gender-sensitive as it offers equal opportunity to male and female participants in this study. This outcome on gender confirms the results of Ezenwosu and Nworgu [75], Eze et al. [20], Ogundola [61], and Mabekoje and Adenuga [81] that established no significant interaction effect of treatment and gender on students' learning outcomes in biology, financial accounting, technical drawing, English, respectively. This implies that relative efficacy of peer tutoring was consistent across gender groups.

Another important finding of this study is that treatment and socioeconomic status had significant interaction effect on students' achievement in financial accounting concepts. This finding disagrees with the findings of Edinyang et al. [82] that discovered the effect of treatment and socioeconomic status on students' achievement and retention in social studies was insignificant. This implies that the interplay of treatment students was exposed to and their parents' SES had effect on students' learning outcome in financial accounting concepts.

\section{Conclusion}

This research focused on the effectiveness of the peer tutoring instructional strategy on the academic achievement of students in financial accounting concepts. The outcome of this research has provided empirical data on the effectiveness of peer tutoring in improving students' academic achievement in financial accounting concepts compared to the conventional lecture method. This is because in a peer tutoring class, students are actively involved in the learning process; it allows the transfer of control to the students in the classroom [83] with active guidance of the teacher; it gives students the opportunity to explain their ideas in a manner that the other tutees will comprehend. On the contrary, the use of the conventional lecture method in delivering financial accounting instruction did not yield the expected results consequent on students' passiveness during the learning process. Conventional lecture method encouraged 
the students to habitually rely on teachers for knowledge transmission which is inimical to sound memory development and could lead to poor academic achievement in financial accounting.

Also, students' gender had no interactive effect with treatment on students' academic achievement in financial accounting concepts, while SES interacted with the treatment on students' academic achievement. Sequel to this finding, the study recommends that post-basic schoolteachers should be encouraged to make use of peer tutoring as a strategy for delivering financial accounting lessons in secondary schools to advance students' attainment in the subject. Also, educational administrators should organize training and seminars to enable financial accounting teachers to become conversant with the peer tutoring instructional strategy. Furthermore, teachers should consider socioeconomic status of students when teaching with peer tutoring instructional strategies. Educational researchers should be aware that the outcome of this study is limited to one hundred and thirty-seven senior secondary school two financial accounting students selected from eight secondary schools in Southern Nigeria. The researchers, therefore, suggested that future research should be conducted in other related disciplines to evaluate the effectiveness of the peer tutoring instructional strategy.

\section{Data Availability}

The data used to support the findings of this study are included within the article.

\section{Conflicts of Interest}

The authors declare no conflicts of interest.

\section{References}

[1] Federal Republic of Nigeria, National Policy on Education, Government Press, Lagos, Nigeria, 6th edition, 2014.

[2] Federal Republic of Nigeria, National Policy on Education, Nigerian Educational Research and Development Council (NERDC), Lagos, Nigeria, 4th edition, 2004.

[3] Federal, Republic of Nigeria, National Policy on Education, NERDC Press, Lagos, Nigeria, 6th edition, 2013.

[4] A. Asaolu, Modern Book-Keeping and Accounts, Calabeks publishers, Ibadan, Nigeria, 2002.

[5] L. M. Abbey and L. J. Okorogba, "Comparative effect of students' academic performance in learning financial accounting using instructional video," International Journal of Advanced Academic Research, vol. 3, no. 12, pp. 24-29, 2017.

[6] U. Inuwa, Z. Abdullah, Z. Abdullah, and H. Hassan, "A mixedmethod study of the effect of the demonstration method on students' achievement in financial accounting," International Journal of Instruction, vol. 11, no. 4, pp. 577-592, 2018.

[7] National Examination Council, Regulations and Syllabus for Senior Secondary School Certificate Examination, NECO, Minna, Nigeria, 2004.

[8] N. P. Francis, "Climate change and implication for senior secondary school financial accounting curriculum development in Nigeria," Journal of Education and Practice, vol. 5, no. 26, pp. 153-157, 2014.
[9] U. Inuwa, Z. Abdullah, and H. Hassan, "Assessing the effect of cooperative learning on financial accounting achievement among secondary school students," International Journal of Instruction, vol. 10, no. 2, pp. 31-46, 2017.

[10] M. S. Adeleke, M. O. Binuomote, and M. S. Adeyinka, "Determinants of students' academic performance in financial accounting among senior secondary school leavers in Oyo State," International Journal of Business and Management Invention, vol. 2, no. 5, pp. 48-59, 2013.

[11] C. Ezeagba, "The problems in the teaching and learning of accounting as a vocational subject in Nigeria secondary schools," AFRREV STECH: An International Journal of Science and Technology, vol. 3, no. 2, pp. 208-226, 2014.

[12] J. O. Ezeugwu, G. C. Nji, N. J. Anyaegbunam, C. Enyi, and R. U. Eneja, "Influence of cognitive ability, gender and school location on students' achievement in senior secondary school financial accounting," European Journal of Economics, Finance and Administrative Sciences, vol. 89, pp. 97-117, 2016.

[13] I. A. Mohammed, "The Challenges of Teaching Financial Accounting in Nigerian Secondary Schools: A Case Study of Gombe State," SSRN Electronic Journal, 2011.

[14] E. C. Osuala, Principles and Methods of Business and Computer Education, Cheston Agency Limited, Enugu, Nigeria, 2004.

[15] J. I. Obidile, S. C. Amobi, H. E. Uzoekwe, and J. A. Akuezilo, "Perceived factors influencing academic performance of students in accounting in secondary schools in Anambra State," IOSR Journal of Humanities and Social Science, vol. 22, no. 2, pp. 96-99, 2017.

[16] L. C. Onyali, A. V. Akinfolarin, and T. S. Famuti, "Relationship between staff human resource management and academic performance of accounting students in secondary schools in Akoko South-West, Ondo State," International Journal for Social Studies, vol. 4, no. 8, pp. 23-32, 2018.

[17] F. C. Nwaukwa and C. C. Okolocha, "Effect of think-pair-share instructional strategy on students' academic achievement and self-efficacy in financial accounting in Abia State," International Journal of Recent Innovations in Academic Research, vol. 4, no. 1, pp. 37-48, 2020.

[18] I. Umar and U. B. Abdulmutallib, "Effects of cooperative and guided discovery approach on financial accounting achievement among secondary school students ATBU," Journal of Science, Technology \& Education, vol. 5, no. 2, pp. 61-70, 2017.

[19] E. Sagor, "What is peer-to-peer learning?," 2008, http://www. wonsagoonline.com/.

[20] T. I. Eze, J. I. Ezenwafor, and I. J. Obidile, "Effects of problembased teaching method on students' academic performance and retention in financial accounting in technical colleges in anambra state," Scholars Journal of Arts, Humanities and Social Sciences, vol. 4, no. 6, pp. 634-639, 2016.

[21] M. A. Melero and P. Fernandez, "Peer learning," in Social Interaction in Educational Contexts, P. Fernandez and M. A. Melero, Eds., SpringerLink, Madrid, Spain, 1995.

[22] J. Rudland and S. Rennie, "Medical faculty opinions of peer tutoring," Education for Health, vol. 27, no. 1, pp. 4-9, 2014.

[23] G. Flores, D. Ibeth, U. Ibarra et al., "Peer tutoring as an improvement strategy for school exploitation," European Journal of Educational Research, vol. 7, no. 4, pp. 953-961, 2018.

[24] W.-Y. Hwang, T.-H. Nguyen, and X.-L. Pham, "Peer tutoring to facilitate cognitive diffusion of English as a foreign language learning: using speech translation and shadowing in familiar authentic contexts," Journal of Educational Computing Research, vol. 57, no. 4, pp. 901-929, 2019. 
[25] K. R. Wentzel, Peers and Academic Functioning at School, Guilford, New York, NY, USA, 2009.

[26] E. L. Deci and R. M. Ryan, "The what and why of goal pursuits: human needs and the self-determination of behavior," Psychological Inquiry, vol. 11, no. 4, pp. 227-268, 2000.

[27] J. M. Hanson, T. L. Trolian, M. B. Paulsen, and E. T. Pascarella, "Evaluating the influence of peer learning on psychological well-being," Teaching in Higher Education, vol. 21, no. 2, pp. 191-206, 2016.

[28] D. Boud, R. Cohen, and J. Sampson, Peer Learning in Higher Education: Learning from and with Each Other, Routledge, Abingdon, UK, 2014.

[29] L. De Backer, H. Van Keer, and M. Valcke, "Promoting university students' metacognitive regulation through peer learning: the potential of reciprocal peer tutoring," Higher Education, vol. 70, no. 3, pp. 469-486, 2015.

[30] A. R. Eslami, M. Hojat, and J. Z. Badiyepeymaie, "Comparison of teaching through peer learning with the lecture method on the learning level of anesthesiology students at Jahrom University of medical sciences in 2013," Journal of Nursing Education, vol. 4, no. 3, pp. 56-65, 2015.

[31] E. N. Azubuike, "Effect of peer tutoring instructional strategy on achievement in biology of senior secondary school slow learners in anambra state," Master thesis, Faculty of Education, Nnamdi Azikiwe University, Awka, Nigeria, 2012.

[32] O. A. Ige, "Effects of value clarification and action learning instructional strategies on school children's attitude to civic education concepts: the mountain learning ecologies experience," Pedagogika, vol. 131, no. 3, pp. 83-98, 2018.

[33] O. A. Ige, "Using action learning, concept-mapping, and value clarification to improve students' attainment in ICT concepts in social studies: the case of rural learning ecologies," Journal of Social Studies Education Research, vol. 10, no. 1, pp. 301322, 2019.

[34] O. A. Ige and D. J. Hlalele, "Effects of computer-aided and blended teaching strategies on students' achievement in civic education concepts in mountain learning ecologies," $E d u$ cation and Information Technologies, vol. 22, no. 6, pp. 2693-2709, 2017.

[35] P. A. Amosun, O. A. Ige, and K.-K. R. Choo, "Impact of a participatory cyber crime prevention programme on secondary school students' attainment in crime prevention concepts in civic education and social studies," Education and Information Technologies, vol. 20, no. 3, pp. 505-518, 2015.

[36] L. Kyei and B. Apam, "Some gender differences in performance in senior high mathematics examinations in mixed high schools," American Journal of Social and Management Sciences, vol. 2, no. 4, pp. 348-355, 2011.

[37] G. Guo and K. M. Harris, "The mechanisms medicating the effects of poverty on children's intellectual development," Demography, vol. 37, no. 4, pp. 431-447, 2007.

[38] A. M. Dahie, M. O. Mohamed, and A. A. Moalim, "Socioeconomic status and academic achievement at secondary schools in Mogadishu-Somalia," International Journal in Management and Social Science, vol. 4, no. 1, pp. 2321-1784, 2016.

[39] N. Rathe and S. Sharma, "Alienation and socio-economic status as correlates of academic status among high school students," IJRAR- International Journal of Research and Analytical Reviews, vol. 5, no. 4, pp. i356-i360, 2018.

[40] L. Moliner and F. Alegre, "Effects of peer tutoring on middle school students' mathematics self-concepts," PLoS ONE, vol. 15, no. 4, Article ID e0231410, 2020.
[41] M. Warschauer, L. Turbee, and B. Roberts, "Computer learning networks and student Empowerment," System, vol. 24, no. 1, pp. 1-14, 1996.

[42] J. Baek, Y. Yoo, K. Lee, B. Jung, and Y. Baek, "Using an instant messenger to learn a foreign language in a peer-tutoring environment," TOJET: The Turkish Online Journal of Educational Technology, vol. 16, no. 2, pp. 145-152, 2017.

[43] M. Cockerill, N. Craig, and A. Thurston, "Teacher perceptions of the impact of peer learning in their classrooms: using social interdependence theory as a model for data analysis and presentation," International Journal of Education and Practice, vol. 6, no. 1, pp. 14-27, 2018.

[44] C. A. Utley and S. L. Mortweet, "Peer-mediated instruction and interventions," Focus on Exceptional Children, vol. 29, pp. 1-23, 1997.

[45] M. Spilles, T. Hagen, and T. Hennemann, "Playing the good behavior game during a peer-tutoring intervention: effects on behavior and reading fluency of tutors and tutees with behavioral problems," Insights Into Learning Disabilities, vol. 16, no. 1, pp. 59-77, 2019.

[46] N. Falchikov and J. Goldfinch, "Student peer assessment in higher education: a meta-analysis comparing peer and teacher marks," Review of Educational Research, vol. 70, no. 3, pp. 287-322, 2000.

[47] J. A. C. Hattie, Visible Learning: A Synthesis of over 800 MetaAnalyses Relating to Achievement, Routledge, London, UK, 2009.

[48] D. W. Johnson, R. T. Johnson, and K. Smith, "The state of cooperative learning in postsecondary and professional settings," Educational Psychology Review, vol. 19, no. 1, pp. 15-29, 2007.

[49] L. Martino, "When students help students," The Executive Educator, vol. 15, no. 1, pp. 31-32, 1993.

[50] M. Prince, "Does active learning work? a review of the research," Journal of Engineering Education, vol. 93, no. 3, pp. 223-231, 2004.

[51] C. A. Rohrbeck, M. D. Ginsburg-Block, J. W. Fantuzzo, and T. R. Miller, "Peer-assisted learning interventions with elementary school students: a meta-analytic review," Journal of Educational Psychology, vol. 94, no. 20, pp. 240-257, 2003.

[52] R. E. Slavin, "Never streaming: preventing learning disabilities," Educational Leadership, vol. 53, no. 5, pp. 4-7, 1996.

[53] L. Springer, M. E. Stanne, and S. S. Donovan, "Effects of smallgroup learning on undergraduates in science, mathematics, engineering, and technology: a meta-analysis," Review of Educational Research, vol. 69, no. 1, pp. 21-51, 1999.

[54] K. J. Topping, "The effectiveness of peer tutoring in further and higher education: a typology and review of the literature," Higher Education, vol. 32, no. 3, pp. 321-345, 1996.

[55] K. Topping, Using Peer Assessment to Inspire Reflection and Learning: Learning by Judging and Discussing the Work of Other Students, Routledge, Abingdon, UK, 2018.

[56] K. Topping, C. Buchs, D. Duran, and H. Van Keer, Effective Peer Learning: From Principles to Practical Implementation, Taylor \& Francis, Oxfordshire, UK, 2017.

[57] K. Topping, "Peer assessment: learning by judging and discussing the work of other learners," Interdisciplinary Education and Psychology, vol. 1, no. 1, p. 7, 2017.

[58] S. Ayvazo and E. Aljadeff-Abergel, "Classwide peer tutoring in a martial arts alternative education program: enhancing social and psychomotor skills," Preventing School Failure: Alternative Education for Children and Youth, vol. 63, no. 4, pp. 359-368, 2019. 
[59] F. Fung, C. Y. Tan, and G. Chen, "Student engagement and mathematics achievement: unraveling main and interactive effects," Psychology in the Schools, vol. 55, no. 7, pp. 815-831, 2018.

[60] B. Rios-Ellis, M. Rascón, G. Galvez, G. Inzunza-Franco, L. Bellamy, and A. Torres, "Creating a model of latino peer education," Education and Urban Society, Education and Urban Society, vol. 47, no. 1, pp. 33-55, 2012.

[61] P. Ogundola, "Effects of peer tutoring strategy on academic achievement of senior secondary school students in technical drawing in Nigeria," British Journal of Education, Society \& Behavioural Science, vol. 19, no. 1, pp. 1-10, 2017.

[62] Y. AbdulRaheem, H. T. Yusuf, and A. O. Odutayo, "Effect of peer tutoring on students' academic performance in economics in Ilorin South, Nigeria," Journal of Peer Learning, vol. 10, no. 2, pp. 95-102, 2017.

[63] O. A. Ige, "Effects of gender and technological fluency on learners' attitude to cyber crime prevention in urban learning ecologies," International Journal of Cyber Criminology, vol. 12, no. 1, pp. 143-163, 2018.

[64] A. Mizala, F. Martínez, and S. Martínez, "Pre-service elementary school teachers' expectations about student performance: how their beliefs are affected by their mathematics anxiety and student's gender," Teaching and Teacher Education, vol. 50, pp. 70-78, 2015.

[65] O. A. Ige, Impact of an action cyber crime prevention programme on secondary school students' learning outcomes in civic education and social studies concepts, Ph.D. thesis, University of Ibadan, Ibadan, Nigeria, 2013.

[66] N. Ting, "Statistical interactions in a clinical trial," Therapeutic Innovation \& Regulatory Science, vol. 52, no. 1, pp. 14-21, 2017.

[67] A. A. Okoye, "Effect of peer tutoring method on students' academic achievement in home Economics," Academic Journal of Interdisciplinary Studies, vol. 2, no. 5, pp. 23-31, 2013.

[68] I. Abdullahi, "Effect of peer tutoring teaching strategy on secondary school students academic achievement in mathematics in tsaragi emirate of edu local government area of Kwara state," M.Ed. thesis, Kwara State University, Malete, Nigeria, 2016.

[69] E. E. Udo, 'Effect of peer tutoring on students' academic performance and retention in junior secondary school basic science," International Journal of Educational Benchmark (Ijeb), vol. 3, no. 1, pp. 97-111, 2016.

[70] A. Tella, "The effect of peer tutoring and explicit instructional strategies on primary school pupils learning outcomes in mathematics," Bulgarian Journal of Science and Education Policy (BJSEP), vol. 7, no. 1, pp. 5-25, 2013.

[71] F. Ke, "Computer-game-based tutoring of mathematics," Computers \& Education, vol. 60, no. 1, pp. 448-457, 2013.

[72] T. Toh and B. Kaur, "Low attainers and learning of mathematics," in Mathematics Education in Singapore-n Asian Perspective, T. Toh, B. Kaur, and E. Tay, Eds., pp. 287-311, Springer, Singapore, Singapore, 2019.

[73] M. Tsuei, "Using synchronous peer tutoring system to promote elementary students' learning in mathematics," Computers \& Education, vol. 58, no. 4, pp. 1171-1182, 2012.

[74] A. O. Chinwuba and E. Osamuyimen, "Academic performance of male versus female accounting undergraduate students: evidence from Nigeria," Canadian Centre of Science and Education, vol. 1, no. 1, pp. 9-19, 2011.

[75] S. U. Ezenwosu and L. N. Nworgu, "Efficacy of peer tutoring and gender on students' achievement in biology,"
International Journal of Scientific and Engineering Research, vol. 4, no. 12, pp. 944-950, 2013.

[76] P. O. Dania, "Effect of gender on students' academic achievement in secondary school social studies," Journal of Education and Practice, vol. 5, no. 21, pp. 78-84, 2014.

[77] J. G. Adewale and O. E. Effiong, "Effects of two methods on students' achievement in Junior secondary schools in Yakurr, Cross River state," International Letters of Social and $\mathrm{Hu}$ manistic Sciences, vol. 61, pp. 70-81, 2015.

[78] E. O. Ebong, "Students' socio-economic background in social studies," M. Ed thesis, Faculty of Education, University of Calabar, Calabar, Nigeria, 2004.

[79] F. N. Mgbado, "The relative effect of socio-economic status and teacher qualification on students' achievement and retention in social studies," M. Ed. Thesis, Faculty of Education, University of Lagos, Lagos, Nigeria, 2002.

[80] A. O. Tina, Effect of the family socio economic status on the academic performance of senior secondary II students in english language in Mbaitoli L. A. of Imo state, Ph.D. Thesis, Department of Curriculum and Teaching. Faculty of Education. University of Calabar, Calabar, Nigeria, 2001.

[81] O. Mabekoje and F. T. Adenuga, "Effects of explicit timing and continuous monitoring assessment strategies on secondary school students' learning outcomes in English grammar," in Proceedings of the 1st Interdisciplinary Conference of UCC-ASUED 2015, A. Arigbabu, Y. A. Ankomah, N. Adetoro, A. B. Baah Bakah, S. E. Oladipo, and K. Boadu, Eds., University of Cape Coast, Cape Coast, Ghana, May, 2015.

[82] S. D. Edinyang, I. E. Ubi, E. E. Usang, and R. A. Adalikwu, "Effects of gender, socio economic status, teacher qualification and their interaction on students' retention ability in social studies in Akwa Ibom State, Nigeria," Journal of Culture, Society and Development, vol. 2, pp. 35-40, 2013.

[83] R. Srivastava and M. Rashid, "Who is at edge - tutors or tutees? academic, social and emotional elevation through peer tutoring," in Arab World English Journal Proceedings of 1st MEC TESOL Conference 2018, pp. 64-77, Muscat, Oman, March 2018. 